Article

\title{
Application of Directly Brewed Compost Extract Improves Yield and Quality in Baby Leaf Lettuce Grown Hydroponically
}

\author{
Almudena Giménez ${ }^{1}$, Juan A. Fernández ${ }^{1,2}{ }^{(0}$, José A. Pascual ${ }^{3}{ }^{\circledR}$, Margarita Ros $^{3}$ and \\ Catalina Egea-Gilabert 1,2,*(D) \\ 1 Departamento Ingeniería Agronómica, Universidad Politécnica de Cartagena, Paseo Alfonso XIII, 48, \\ 30203 Cartagena, Spain; almudena.gimenez@upct.es (A.G.); juan.fernandez@upct.es (J.A.F.) \\ 2 Instituto de Biotecnología Vegetal, Edificio I+D+i, Campus Muralla del Mar, 30202 Cartagena, Spain \\ 3 Conservación de suelos y Agua y Manejo de Residuos Orgánicos, CEBAS-CSIC, Campus de Espinardo, E-, \\ 30100 Murcia, Spain; jpascual@cebas.csic.es (J.A.P.); margaros@cebas.csic.es (M.R.) \\ * Correspondence: catalina.egea@upct.es; Tel.: +34-968-325520
}

Received: 28 January 2020; Accepted: 4 March 2020; Published: 7 March 2020

check for updates

\begin{abstract}
The aim of this work was to study whether the application of a directly brewed compost extract (added in the nutrient solution or by microsprinkler) could be used to improve the yield and quality of baby leaf red lettuce growing in a floating system, and to control the incidence of Pythium irregulare. Its effect on the quality of fresh-cut red lettuce was also studied. For this, two experiments were carried out over two growing cycles (winter-spring and autumn). The results showed that the use of compost extract added to the nutrient solution improved baby leaf lettuce growth and quality, reducing the nitrate content and enhancing the content of potentially health-promoting compounds such as phenols and flavonoids and the antioxidant capacity. Microbial quality was maintained during storage and the compost extract had no negative effect on the microbial load of the final product. In addition, application of the compost decreased the population of $P$. irregulare in the water. It is concluded that the application of directly brewed compost extract is of potential use in a sustainable soilless production system for baby leaf red lettuce, since it improves the yield and quality of the product and is able to control the incidence of P. irregulare.
\end{abstract}

Keywords: Lactuca sativa; Pythium irregulare; nitrate; postharvest; antioxidant capacity; total phenolics

\section{Introduction}

The use of compost in agriculture is gradually gaining in popularity, mainly due to its environmental and agronomic benefits. In addition, compost can be considered as a key element in the circular economy, allowing a more sustainable production system [1]. More particularly, composts from the fruit and vegetable processing industry are used as a nutrient-rich fertilizer or soil amendment to improve crop production and quality [2-4]. Furthermore, such composts present a lower risk of containing pathogens, heavy metals or pharmaceuticals as components [5], and have interesting biological activities [6]. Some composts have shown an ability to suppress soil-borne diseases [2,7], in which the microbial activity of the compost plays a major role [8,9]. However, some abiotic properties have also been suggested to be associated with suppression activity [10]. It has been demonstrated that the suppressive effect of composts depends on the raw material origin, the pathogen to be controlled and the plant being cultivated [7].

The suitability of using compost in the soilless culture of horticultural crops has also been confirmed in several studies, particularly when it is used as a substrate for the nursery production of vegetable crops $[4,11]$. However, few studies have been carried out on the use of compost in crops 
grown hydroponically. Recent studies have demonstrated that an agroindustrial compost can be used as an alternative to peat organic substrate in a floating system, since it is not only able to control Pythium irregulare, but also to improve the yield and quality of the crop [12,13].

Compost-derived products, such as compost extract (CE), are used as a source of nutrients to improve crop production, and as an inducer of systemic acquired resistance against soil-borne diseases [14-17], allowing a more sustainable production system. Depending on the origin of the compost and the way in which the CE is obtained, CEs have different compositions, although they are mainly composts of a mixture of humic and fulvic acids, organic molecules and soluble inorganic substances carried in suspension $[18,19]$. It has been demonstrated that this type of compound has a direct effect on some metabolic processes [20-23]. The biostimulant capacity of a CE is exercised through direct and/or indirect effects on nutrition, leading to hormone-like activity that influences the photosynthetic capacity of the plant [21,22]. Arancon et al. 2012 [20] suggested that analogs of hormones contained in vermicompost extracts were responsible for aiding plant growth and increasing yield.

As is the case with most composts, the potential mechanism of suppression of CE is often, or predominantly, biological, although chemical and physical factors have also been implicated [24]. The application of CE has been shown to significantly suppress several pathogens such as bacterial spot on tomato [25], Botrytis cinerea on strawberry [26] and foliar fungal pathogen on tomato [27]. CEs have normally been used as a soil drench or directly sprayed on plants [28-31], but, to our knowledge, their use in hydroponic systems has not been studied in depth before. The use of directly brewed CE has been studied even less despite the fact that they could be a valuable tool in hydroponic management [20]. Our hypothesis was that a CE obtained by passing aerated water through a fine mesh bag containing compost in a floating bed or inside an irrigation tank for subsequent spraying by microsprinkler would stimulate plant growth and help control diseases. For this, we studied the effect of two different ways of applying a directly brewed compost extract added in the nutrient solution (CENS) or by microsprinkler (CEMP) on the yield and quality of baby leaf red lettuce growing in a floating system, and the effect on the incidence of Pythium irregulare. In addition, the quality of fresh-cut red lettuce produced in this way was studied.

\section{Materials and Methods}

\subsection{Plant Material and Growing Conditions}

The experiments were conducted in the Agricultural Experimental Field Station of the Technical University of Cartagena (UPCT; lat. $37^{\circ} 41^{\prime} \mathrm{N}$; long. $0^{\circ} 57^{\prime} \mathrm{W}$ ). A cultivar of red baby leaf lettuce (Lactuca sativa L.), "Antoria" (Rijk Zwaan, De Lier, The Netherlands), was cultivated in a floating system in an unheated greenhouse covered with thermal polyethylene. Two crop cycles were carried out with sowings on 27 February 2017 (winter-spring cycle) and 3 October 2017 (autumn cycle) in styrofloat trays measuring $60 \times 40 \mathrm{~cm}$ [12], which were filled with a commercial peat substrate (Pindstrup Blond Gold). After sowing, the trays were transferred to flotation beds $(1.35 \times 1.25 \times 0.2 \mathrm{~m})$, floating on tap water with an electrical conductivity (EC) of $1.1 \mathrm{dS} \mathrm{m}^{-1}$ and $\mathrm{pH}$ 7.8. Aeration was provided using a blow pump connected to a perforated pipe trellis positioned at the bottom of each flotation bed.

A week after sowing, the lettuce plants were thinned, leaving 8 plants per cell $\left(1600\right.$ plants $\left.\mathrm{m}^{-2}\right)$. At the same time, the tap water in the beds was replaced with a nutrient solution $\left(8 \mathrm{mM} \mathrm{NO}_{3}{ }^{-}, 2 \mathrm{mM}\right.$ $\mathrm{NH}_{4}{ }^{+}, 2 \mathrm{mM} \mathrm{H}_{2} \mathrm{PO}_{4}{ }^{-}, 2.6 \mathrm{mM} \mathrm{Ca}^{2+}, 4.65 \mathrm{mM} \mathrm{K}^{+}$and $1.12 \mathrm{mM} \mathrm{Mg}^{2+}$, plus a commercial solution of microelement Nutromix 10, Biagro $\left(2 \mathrm{mg} \mathrm{L}^{-1}\right)$ and Sequestrene (an Iron chelate) $\left(1.5 \mathrm{mg} \mathrm{L}^{-1}\right)$ ) [32]. The nutrient solution was adjusted to EC $2.5 \mathrm{dS} \mathrm{m}^{-1}$ and $\mathrm{pH} 5.8$. The EC and temperature of the nutrient solution and the oxygen concentration were monitored throughout the growing cycles using sensors located in each flotation bed. The dissolved oxygen concentration, EC and temperature ranged from 6.5 to $8.7 \mathrm{mg} \mathrm{L}^{-1}$, from 2.5 to $3.6 \mathrm{dS} \mathrm{m}^{-2}$ and from 12 to $28^{\circ} \mathrm{C}$, respectively, for the winter-spring cycle, and, from 5.5 to $8.6 \mathrm{mg} \mathrm{L}^{-1}$, from 2.5 to $3.4 \mathrm{dS} \mathrm{m}^{-2}$ and from 16 to $27^{\circ} \mathrm{C}$, respectively for the autumn cycle. The light conditions and temperature during the experiments were an average daily 
light integral (DLI) of $7.42 \mathrm{~mol} \mathrm{~m}^{-2} \mathrm{~d}^{-1}$, and $6.39^{\circ} \mathrm{C}, 38.72{ }^{\circ} \mathrm{C}$ and $19.56^{\circ} \mathrm{C}$ (minimum, maximum and average air temperature) in the winter-spring cycle; and an average DLI of $4.27 \mathrm{~mol} \mathrm{~m}^{-2} \mathrm{~d}^{-1}$, and $12.61{ }^{\circ} \mathrm{C}, 40.01^{\circ} \mathrm{C}$ and $23.21^{\circ} \mathrm{C}$ (minimum, maximum and average air temperature) in the autumn cycle.

Harvesting was carried out at the same phenological stage for both cycles, when the plants had four to five leaves. This occurred 30 days after sowing in the winter-spring and after 25 days in the autumn cycle. Seventy-two plants from three randomly chosen cells from each tray were harvested for each treatment for postharvest analysis. Water from floating bed samples was collected and stored at $-20{ }^{\circ} \mathrm{C}$ to measure pathogen concentrations.

\subsection{Compost Extract Characteristics and Application}

The compost used to produce the CE was provided by CEBAS-CSIC. The raw materials for composting expressed as dry weight, were tomato $(71 \%)$, onion $(17 \%)$ and vineyard residues $(12 \%)$. Composting was carried out in open-air piles, with a bioxidative and maturation phases of 75 and 42 days, respectively. The piles were turned periodically to ensure aeration, and to control the temperature. Once the composting process had finished (120 days), the compost was milled and passed through a 2-cm sieve. The main characteristics of the compost are shown in Giménez et al. 2019 [12].

The CE was obtained by passing aerated water through a fine mesh bag containing $150 \mathrm{~g}$ compost. The bags were placed in the nutrient solution contained in each flotation beds (CENS) or inside the irrigation tank used to apply the CE by microsprinkler (CEMP). Microsprinkler irrigation was scheduled three days per week for 3-5 min, morning and afternoon. The bags containing the compost were placed in the above-mentioned water deposits a week after sowing and kept in situ until harvesting. The control treatment (C) did not contain CE.

The ion content of the CE was analyzed and quantified by ion chromatography [33] in the water emitted by the microsprinklers and in the water contained in the flotation beds before adding the nutrient solution (Table 1).

Table 1. Chemical characteristics of compost extract for the two ways of application (CENS: compost extract in the nutrient solution, CEMP: compost extract delivered by microsprinkler) recorded 7 days after sowing.

\begin{tabular}{cccccccc}
\hline & $\begin{array}{c}\mathrm{NO}_{3}{ }^{-} \\
\left(\mathbf{m g ~ L}^{-1}\right)\end{array}$ & $\begin{array}{c}\mathbf{S O}_{4}{ }^{2-} \\
\left(\mathbf{m g ~ L}^{-1}\right)\end{array}$ & $\begin{array}{c}\mathrm{Cl}^{-} \\
\left(\mathbf{m g ~ L}^{-1}\right)\end{array}$ & $\begin{array}{c}\mathbf{N a}^{+} \\
\left(\mathbf{m g ~ L}^{-1}\right)\end{array}$ & $\begin{array}{c}\mathbf{K}^{+} \\
\left(\mathbf{m g ~ L}^{-1}\right)\end{array}$ & $\begin{array}{c}\mathbf{M g}^{2+} \\
\left(\mathbf{m g ~ L}^{-1}\right)\end{array}$ & $\begin{array}{c}\mathbf{C a}^{2+} \\
\left(\mathbf{m g ~ L}^{-1}\right)\end{array}$ \\
\hline CENS & 13.6 & 143.2 & 170.6 & 109.4 & 26.9 & 30.3 & 77.2 \\
\hline CEMP & 13.4 & 143.5 & 176.1 & 115.6 & 21.9 & 30.0 & 77.0 \\
\hline
\end{tabular}

\subsection{Pathogen and Inoculation}

To evaluate the effectiveness of the CE for the biological control of Pythium irregulare, the pathogen was added to the flotation beds 5 days after sowing. The pathogen solution was prepared by blending a 7-day old P. irregulare culture grown on potato dextrose agar (PDA) in $100 \mathrm{~mL}$ of distilled water for one minute. The dose added to the flotation beds was $100 \mathrm{~mL}$ in $200 \mathrm{~L}$ water, the equivalent to $2.6 \times 10^{3}$ copies ITS per mL. The abundance of $P$. irregulare in the inoculated substrates was measured as described by Giménez et al. 2019 [13].

\subsection{Analysis at Harvesting Time}

At harvesting time, the following parameters were analyzed: biomass production (yield), calculated as g plant $^{-1}$; dry matter content (\%) of shoots; specific leaf area (SLA); root growth; number of adventitious roots. The dry matter contents were determined by drying in an oven at $50^{\circ} \mathrm{C}$ until a constant weight. The leaf area was measured with a leaf area meter (LICOR-3100 C; LICOR Biosciences Inc., Lincoln, NE, USA). Total root length, the length of $0-0.5 \mathrm{~mm}$ diameter root and root diameter per plant were determined using Winrhizo LA 1600 root counter (Regent Inc., Quebec City, QC, Canada). 
The nitrate content in leaves and in the water of the irrigation systems was analyzed in triplicate using $0.2 \mathrm{~g}$ of dry leaf samples per treatment and quantified by ion chromatography [33]. The total phenolic content was determined by the Folin-Ciocalteu colorimetric method [34]. The antioxidant capacity was evaluated in terms of their free radical-scavenging capacity [35]. The total flavonoid content was determined as described by [36].

\subsection{Postharvest Product Management and Analysis}

The postharvest analysis was only performed in non-inoculated plants. Harvested leaves were placed in plastic bags and immediately transported $6 \mathrm{~km}$ in a box with ice to the Instituto de Biotecnología Vegetal of the UPCT where they were kept for $4 \mathrm{~h}$ at $5{ }^{\circ} \mathrm{C}$. The leaves were disinfected, washed and packed following Niñirola et al. 2014 [37]. Then, $20 \mathrm{~g}$ of leaves were placed in polypropylene (PP) baskets of $1 \mathrm{~L}$ capacity, the tops of which were thermosealed with a 34-mm thick film composed of polyethylene terephthalate (PET) + oriented polypropylene (OPP) and stored at $5{ }^{\circ} \mathrm{C}$ for 7 days.

Microbial growth, for both mesophilic and psychrophilic microorganisms, was assessed following Niñirola et al. 2014 [37] after processing and after $7 \mathrm{~d}$ of storage. The nitrate, total phenolic, total flavonoid contents and antioxidant capacity were measured as described above after 7 days of storage.

\subsection{Experimental Design and Statistical Analysis}

A randomized complete block design with three replicates per way of CE application was used in the greenhouse in both growing seasons. Each bed had three floating trays. Data were analyzed using Statgraphics Plus. An analysis of variance of agronomical and biochemical parameters (two-way ANOVA) was performed, in which the CE application (Control, CENS and CEMP) and inoculation (non-inoculation and inoculation with P. irregulare) were included for each crop cycle. Furthermore, an analysis of variance was performed for the biochemical parameters and microbial content for each crop cycle in the postharvest assay CE application (Control, CENS and CEMP) and storage time (0 and 7 days). When interactions were significant, they were included in the ANOVA, and a least significant difference test was performed to compare ways of application, inoculation and storage time.

\section{Results}

\subsection{Growth and Yield of Lettuce at Harvesting Time}

The fresh biomass (yield) of lettuce was affected by the way of CE application in both growing cycles, while yield was only affected by pathogen inoculation in the winter-spring cycle, reducing it by ca. $8 \%$ (Tables 2 and 3). The highest yield was recorded in plants grown with CENS. In the winter-spring cycle, there was a statistically significant interaction between pathogen inoculation and way of CE application in terms of percentage of dry matter and SLA. The higher values of dry matter were obtained in control inoculated plants and those treated by CENS. Inoculation decreased the SLA values in every combination of factors. In the autumn cycle, there were no significant differences in dry matter for inoculation treatment, way of CE application or their interaction (Table 3). In regards to SLA, there was a statistically significant interaction between pathogen inoculation and way of CE application, the highest values being obtained in inoculated plants. As regards root growth (total root length, length of 0 to $0.5 \mathrm{~mm}$ diameter roots (fine roots) and root diameter), there was a significant interaction between both factors in both growing cycles, except the length of fine roots in the autumn cycle. The greatest total root length and fine roots were achieved with CENS in both growing cycles. The greatest length of fine roots was also obtained with the CENS application. In addition, the inoculation with P. irregulare decreased the total length of roots and fine roots in both growing cycles. Inoculation increased the root diameter in every factor combination. 
Table 2. Influence of inoculation with Pythium irregulare (NI: non-inoculated, I: inoculated) and way of compost extract application (C: control, CENS: compost extract in the nutrient solution, CEMP: compost extract delivered by microsprinkler) on growth parameters (fresh biomass, leaf area, total root length, root diameter and length of $0-0.5 \mathrm{~mm}$ diameter root) at harvest, in baby leaf red lettuce cultivated in the winter-spring cycle in a floating system.

\begin{tabular}{|c|c|c|c|c|c|c|}
\hline & $\begin{array}{c}\text { Fresh } \\
\text { Biomass (g } \\
\text { Plant }^{-1} \text { ) }\end{array}$ & $\begin{array}{c}\text { Dry Matter } \\
(\%)\end{array}$ & SLA $\left(m^{2} \mathrm{~kg}^{-1}\right)$ & $\begin{array}{l}\text { Total Root } \\
\text { Length (cm) }\end{array}$ & $\begin{array}{c}\text { Root } \\
\text { Diameter } \\
(\mathrm{mm})\end{array}$ & $\begin{array}{l}\text { Length of } 0 \text { to } \\
0.5 \mathrm{~mm} \text { Diam. } \\
\text { Root }(\mathrm{cm})\end{array}$ \\
\hline \multicolumn{7}{|l|}{ Inoculation (A) } \\
\hline NI & $2.16 \pm 0.04 \mathrm{~b}$ & $3.76 \pm 0.07 b$ & $81.08 \pm 0.73 b$ & $307.61 \pm 5.30 \mathrm{~b}$ & $0.54 \pm 0.01 \mathrm{a}$ & $248.59 \pm 4.22 b$ \\
\hline I & $1.98 \pm 0.04 \mathrm{a}$ & $4.19 \pm 0.08 \mathrm{a}$ & $75.06 \pm 0.82 \mathrm{a}$ & $176.57 \pm 2.97 \mathrm{a}$ & $0.64 \pm 0.01 \mathrm{~b}$ & $137.73 \pm 2.77 \mathrm{a}$ \\
\hline \multicolumn{7}{|l|}{ Application (B) } \\
\hline C & $2.00 \pm 0.05 a$ & $4.14 \pm 0.10 \mathrm{~b}$ & $80.27 \pm 1.40 \mathrm{~b}$ & $232.28 \pm 8.09 b$ & $0.69 \pm 0.01 \mathrm{~b}$ & $186.19 \pm 6.65 b$ \\
\hline CENS & $2.22 \pm 0.05 b$ & $4.04 \pm 0.10 \mathrm{~b}$ & $75.07 \pm 0.61 \mathrm{a}$ & $289.65 \pm 4.31 \mathrm{c}$ & $0.56 \pm 0.01 \mathrm{a}$ & $239.43 \pm 6.65 c$ \\
\hline CEMP & $2.00 \pm 0.04 \mathrm{a}$ & $3.76 \pm 0.08 \mathrm{a}$ & $78.87 \pm 0.72 \mathrm{ab}$ & $204.36 \pm 8.41 \mathrm{a}$ & $0.54 \pm 0.01 \mathrm{a}$ & $153.86 \pm 3.54 \mathrm{a}$ \\
\hline \multicolumn{7}{|l|}{$A \times B$} \\
\hline $\mathrm{NI} \times \mathrm{C}$ & $2.05 \pm 0.07$ & $3.60 \pm 0.13 \mathrm{a}$ & $90.36 \pm 1.26 \mathrm{~d}$ & $311.96 \pm 7.08 \mathrm{~d}$ & $0.66 \pm 0.01 \mathrm{~d}$ & $256.73 \pm 3.61 \mathrm{c}$ \\
\hline $\mathrm{NI} \times \mathrm{CENS}$ & $2.32 \pm 0.07$ & $3.62 \pm 0.10 \mathrm{a}$ & $80.34 \pm 0.70 \mathrm{~b}$ & $368.81 \pm 7.85 \mathrm{e}$ & $0.46 \pm 0.02 \mathrm{a}$ & $300.65 \pm 6.32 \mathrm{~d}$ \\
\hline $\mathrm{NI} \times \mathrm{CEMP}$ & $2.12 \pm 0.06$ & $3.45 \pm 0.10 \mathrm{a}$ & $85.18 \pm 0.71 \mathrm{c}$ & $242.06 \pm 3.94 \mathrm{c}$ & $0.53 \pm 0.01 \mathrm{~b}$ & $188.40 \pm 5.37 b$ \\
\hline $\mathrm{I} \times \mathrm{C}$ & $1.96 \pm 0.07$ & $4.68 \pm 0.14 \mathrm{c}$ & $72.55 \pm 0.56 \mathrm{a}$ & $152.59 \pm 3.64 \mathrm{a}$ & $0.72 \pm 0.02 \mathrm{e}$ & $115.65 \pm 2.68 \mathrm{a}$ \\
\hline $\mathrm{I} \times \mathrm{CENS}$ & $2.12 \pm 0.08$ & $4.46 \pm 0.15 c$ & $70.19 \pm 1.76 a$ & $211.49 \pm 4.98 b$ & $0.64 \pm 0.01 \mathrm{~d}$ & $178.21 \pm 4.37 \mathrm{~b}$ \\
\hline $\mathrm{I} \times \mathrm{CEMP}$ & $1.88 \pm 0.05$ & $4.07 \pm 0.12 \mathrm{~b}$ & $69.79 \pm 0.34 \mathrm{a}$ & $166.65 \pm 3.76 \mathrm{a}$ & $0.59 \pm 0.01 \mathrm{c}$ & $119.31 \pm 2.21 \mathrm{a}$ \\
\hline \multicolumn{7}{|l|}{ Significance } \\
\hline Inoculation (A) & ** & $* * *$ & $* * *$ & $* * *$ & $* * *$ & $* * *$ \\
\hline Application (B) & $* *$ & $* * *$ & $* * *$ & $* * *$ & $* * *$ & $* * *$ \\
\hline$A \times B$ & n.s. & $* *$ & $* * *$ & $* * *$ & $* * *$ & $* * *$ \\
\hline
\end{tabular}

Asterisk indicates significances at ${ }^{*} p<0.05 ;{ }^{* *} p<0.01 ; * * * p<0.001 ;$ n.s: non-significant. Different letters indicate significant differences. Values are the mean $\pm \operatorname{SD}(n=20)$.

Table 3. Influence of inoculation with Pythium irregulare (NI: non-inoculated, I: inoculated) and way of compost extract application (C: control, CENS: compost extract in the nutrient solution, CEMP: compost extract delivered by microsprinkler) on growth parameters (fresh biomass, leaf area, total root length, root diameter and length of $0-0.5 \mathrm{~mm}$ diameter root) at harvest, in baby leaf red lettuce cultivated in autumn cycle in a floating system.

\begin{tabular}{|c|c|c|c|c|c|c|}
\hline & $\begin{array}{c}\text { Fresh } \\
\text { Biomass ( } \\
\text { Plant }^{-1} \text { ) }\end{array}$ & $\begin{array}{l}\text { \% Dry } \\
\text { Matter }\end{array}$ & SLA $\left(\mathrm{m}^{2} \mathrm{~kg}^{-1}\right)$ & $\begin{array}{l}\text { Total Root } \\
\text { Length }(\mathrm{cm})\end{array}$ & $\begin{array}{c}\text { Root } \\
\text { Diameter } \\
(\mathrm{mm})\end{array}$ & $\begin{array}{l}\text { Length of } 0 \text { to } \\
0.5 \mathrm{~mm} \text { Diam. } \\
\text { Root }(\mathrm{cm})\end{array}$ \\
\hline \multicolumn{7}{|l|}{ Inoculation (A) } \\
\hline $\mathrm{NI}$ & $1.49 \pm 0.02$ & $4.43 \pm 0.07$ & $76.40 \pm 0.51$ & $164.24 \pm 2.74 \mathrm{~b}$ & $0.29 \pm 0.01 \mathrm{a}$ & $138.79 \pm 1.92 b$ \\
\hline I & $1.45 \pm 0.03$ & $4.41 \pm 0.08$ & $76.20 \pm 0.66$ & $148.62 \pm 2.13 \mathrm{a}$ & $0.32 \pm 0.01 \mathrm{~b}$ & $132.01 \pm 1.85 \mathrm{a}$ \\
\hline \multicolumn{7}{|l|}{ Application (B) } \\
\hline $\mathrm{C}$ & $1.49 \pm 0.03 \mathrm{~b}$ & $4.30 \pm 0.10$ & $79.05 \pm 1.66 b$ & $156.07 \pm 2.70 \mathrm{~b}$ & $0.28 \pm 0.01 \mathrm{a}$ & $136.40 \pm 2.31 \mathrm{~b}$ \\
\hline CENS & $1.52 \pm 0.03 \mathrm{~b}$ & $4.45 \pm 0.10$ & $74.94 \pm 1.79 \mathrm{a}$ & $176.13 \pm 3.21 \mathrm{c}$ & $0.31 \pm 0.01 \mathrm{~b}$ & $148.58 \pm 2.04 \mathrm{c}$ \\
\hline CEMP & $1.39 \pm 0.03 \mathrm{a}$ & $4.49 \pm 0.08$ & $74.91 \pm 1.07 \mathrm{a}$ & $138.60 \pm 2.37 \mathrm{a}$ & $0.32 \pm 0.01 \mathrm{~b}$ & $121.22 \pm 1.97 \mathrm{a}$ \\
\hline \multicolumn{7}{|l|}{$A \times B$} \\
\hline $\mathrm{NI} \times \mathrm{C}$ & $1.52 \pm 0.04$ & $4.26 \pm 0.13$ & $79.40 \pm 0.82 \mathrm{~b}$ & $164.66 \pm 4.01 \mathrm{c}$ & $0.24 \pm 0.01 \mathrm{a}$ & $143.58 \pm 3.30$ \\
\hline $\mathrm{NI} \times \mathrm{CENS}$ & $1.55 \pm 0.05$ & $4.39 \pm 0.13$ & $76.31 \pm 0.99 \mathrm{ab}$ & $190.63 \pm 4.51 \mathrm{~d}$ & $0.32 \pm 0.01 \mathrm{bc}$ & $149.20 \pm 2.85$ \\
\hline $\mathrm{NI} \times \mathrm{CEMP}$ & $1.40 \pm 0.04$ & $4.62 \pm 0.13$ & $76.33 \pm 0.53 b$ & $140.44 \pm 3.48 \mathrm{ab}$ & $0.30 \pm 0.01 \mathrm{~b}$ & $123.60 \pm 2.97$ \\
\hline $\mathrm{I} \times \mathrm{C}$ & $1.47 \pm 0.05$ & $4.34 \pm 0.15$ & $78.71 \pm 2.76 b$ & $147.48 \pm 3.30 \mathrm{~b}$ & $0.31 \pm 0.01 b c$ & $129.23 \pm 2.45$ \\
\hline
\end{tabular}


Table 3. Cont.

\begin{tabular}{|c|c|c|c|c|c|c|}
\hline & $\begin{array}{c}\text { Fresh } \\
\text { Biomass (g } \\
\text { Plant }^{-1} \text { ) }\end{array}$ & $\begin{array}{l}\% \text { Dry } \\
\text { Matter }\end{array}$ & SLA $\left(\mathrm{m}^{2} \mathrm{~kg}^{-1}\right)$ & $\begin{array}{l}\text { Total Root } \\
\text { Length (cm) }\end{array}$ & $\begin{array}{c}\text { Root } \\
\text { Diameter } \\
(\mathrm{mm})\end{array}$ & $\begin{array}{l}\text { Length of } 0 \text { to } \\
0.5 \mathrm{~mm} \text { Diam. } \\
\text { Root }(\mathrm{cm})\end{array}$ \\
\hline $\mathrm{I} \times \mathrm{CENS}$ & $1.50 \pm 0.05$ & $4.51 \pm 0.15$ & $73.57 \pm 1.54 \mathrm{a}$ & $161.62 \pm 3.83 c$ & $0.33 \pm 0.01 \mathrm{c}$ & $147.97 \pm 2.74$ \\
\hline $\mathrm{I} \times \mathrm{CEMP}$ & $1.39 \pm 0.04$ & $4.37 \pm 0.11$ & $73.48 \pm 0.68 \mathrm{a}$ & $136.77 \pm 3.27 \mathrm{a}$ & $0.33 \pm 0.01 \mathrm{c}$ & $118.83 \pm 2.79$ \\
\hline \multicolumn{7}{|l|}{ Significance } \\
\hline Inoculation (A) & n.s. & n.s. & n.s. & $* * *$ & $* * *$ & $* *$ \\
\hline Application (B) & $* *$ & n.s. & $* *$ & $* * *$ & $* *$ & $* * *$ \\
\hline $\mathrm{A} \times \mathrm{B}$ & n.s. & n.s. & $* *$ & $* * *$ & $* * *$ & n.s. \\
\hline
\end{tabular}

Asterisk indicates significances at ${ }^{*} p<0.05 ;{ }^{* *} p<0.01 ; * * * p<0.001 ;$ n.s: non-significant. Different letters indicate significant differences. Values are the mean $\pm \operatorname{SD}(n=20)$.

The content of $P$. irregulare in the nutrient solution was significantly reduced by both CE treatments compared with the control, with no significant difference between them (Figure 1). There were no significant differences between the pathogen content of spring-winter and autumn growth cycles.
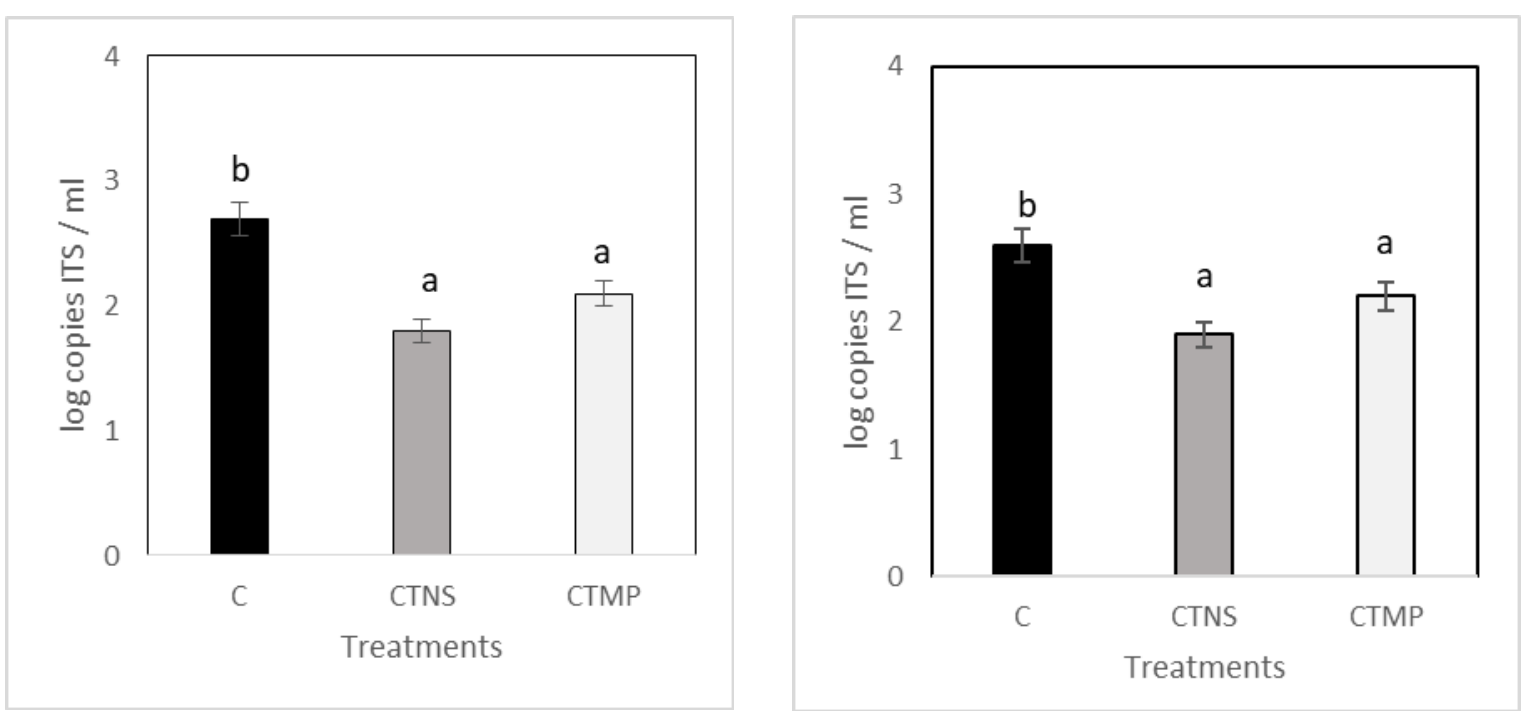

Figure 1. Pythium irregulare in the water at harvesting time in the winter-spring (left) and autumn (right) cycles according to the different ways of compost extract application (C: control, CENS: compost extract in the nutrient solution, CEMP: compost extract delivered by microsprinkler). Values are the mean \pm SD $(n=4)$. Different letters indicate significant differences.

\subsection{Nutritional and Microbiological Quality of Fresh-Cut Product}

In the winter-spring cycle, the nitrate content was affected by the way of $\mathrm{CE}$ application and storage (Table 4). The leaves of plants grown with CEMP had the lowest content. There was a significant interaction between the way of CE application and storage in the autumn cycle (Table 5), the lowest value is found with the CEMP application. After 7 days of storage at $5{ }^{\circ} \mathrm{C}$, the nitrate content had significantly decreased ( $31 \%$ and $58 \%$ in winter-spring and autumn, respectively); once again the CEMP treatment leading to the lowest nitrate content. 
Table 4. Influence of way of compost extract application (C: control, CENS: compost extract in the nutrient solution, CEMP: compost extract delivered by microsprinkler) and storage ( 0 and 7 days) at $5{ }^{\circ} \mathrm{C}$ on the quality (nitrate, total phenolics, total flavonoids and antioxidant capacity) and microbial load (mesophilic and psychrophilic microorganisms) of baby leaf red lettuce cultivated in winter-spring cycle in a floating system.

\begin{tabular}{|c|c|c|c|c|c|c|}
\hline & $\begin{array}{c}\text { Nitrate }\left(\mathrm{mg} \mathrm{kg} \mathbf{~ k g}^{-1}\right. \\
\text { FW) }\end{array}$ & $\begin{array}{l}\text { Total Phenolics (mg } \\
\text { GA kg } \text { kd }^{-1} \text { FW) }\end{array}$ & $\begin{array}{l}\text { Total Flavonoids (mg } \\
\text { Rutin } \mathbf{k g}^{-1} \text { FW) }\end{array}$ & $\begin{array}{c}\text { Antioxidant Capacity } \\
(\mathrm{mg} \mathrm{DPPH} \\
\text { reduced } \mathrm{kg}^{-1} \\
\end{array}$ & $\begin{array}{c}\text { Mesophilic } \\
\text { Microorganisms } \\
\left(\log \text { CFU g }^{-1}\right)\end{array}$ & $\begin{array}{c}\text { Psychrophilic } \\
\text { Microorganisms } \\
\left(\text { Log CFU g }{ }^{-1}\right)\end{array}$ \\
\hline \multicolumn{7}{|l|}{ Application (A) } \\
\hline $\mathrm{C}$ & $1379.76 \pm 74.91 \mathrm{~b}$ & $1044.02 \pm 151.38 \mathrm{a}$ & $1912.56 \pm 162.07 \mathrm{a}$ & $105.32 \pm 9.57 \mathrm{a}$ & $3.57 \pm 0.24$ & $3.74 \pm 0.38 b$ \\
\hline CENS & $1290.69 \pm 71.72 b$ & $1168.74 \pm 137.57 \mathrm{~b}$ & $2691.93 \pm 92.71 b$ & $120.84 \pm 7.49 b$ & $3.48 \pm 0.25$ & $3.59 \pm 0.64 \mathrm{a}$ \\
\hline CEMP & $1079.91 \pm 61.10 \mathrm{a}$ & $1280.77 \pm 131.99 c$ & $2917.70 \pm 80.25 b$ & $141.93 \pm 12.74 \mathrm{c}$ & $3.59 \pm 0.27$ & $3.99 \pm 0.37 c$ \\
\hline \multicolumn{7}{|l|}{ Storage (B) } \\
\hline 0 days & $1491.93 \pm 39.58 b$ & $1727.93 \pm 41.73 b$ & $2872.28 \pm 77.43 b$ & $159.37 \pm 6.39 \mathrm{~b}$ & $2.74 \pm 0.05 \mathrm{a}$ & $2.23 \pm 0.13 \mathrm{a}$ \\
\hline 7 days & $1007.27 \pm 38.22 \mathrm{a}$ & $604.09 \pm 25.58 \mathrm{a}$ & $2142.51 \pm 126.60 \mathrm{a}$ & $86.02 \pm 12.88 \mathrm{a}$ & $4.35 \pm 0.09 \mathrm{~b}$ & $5.32 \pm 0.07 b$ \\
\hline \multicolumn{7}{|l|}{$\mathrm{A} \times \mathrm{B}$} \\
\hline $\mathrm{C} \times 0$ days & $1636.46 \pm 49.72$ & $1636.45 \pm 98.01$ & $2550.72 \pm 98.89$ bc & $141.22 \pm 7.71 \mathrm{c}$ & $2.88 \pm 0.06$ & $2.41 \pm 0.02 \mathrm{~b}$ \\
\hline CENS $\times 0$ days & $1582.35 \pm 58.61$ & $1717.41 \pm 67.29$ & $3009.85 \pm 88.43$ de & $148.76 \pm 6.47 \mathrm{c}$ & $2.67 \pm 0.12$ & $1.47 \pm 0.003 \mathrm{a}$ \\
\hline CEMP $\times 0$ days & $1300.96 \pm 43.94$ & $1820.92 \pm 26.62$ & $3056.26 \pm 149.35 \mathrm{e}$ & $188.14 \pm 11.73 \mathrm{~d}$ & $2.68 \pm 0.03$ & $2.76 \pm 0.02 c$ \\
\hline CENS $\times 7$ days & $1043.04 \pm 55.61$ & $620.06 \pm 25.37$ & $2374.01 \pm 58.67 b$ & $92.93 \pm 1.46 b$ & $4.29 \pm 0.07$ & $5.71 \pm 0.03 \mathrm{f}$ \\
\hline CEMP $\times 7$ days & $855.70 \pm 39.27$ & $740.62 \pm 20.03$ & $2779.13 \pm 16.20 \mathrm{~cd}$ & $95.73 \pm 4.34 \mathrm{~b}$ & $4.51 \pm 0.06$ & $5.21 \pm 0.04 \mathrm{e}$ \\
\hline \multicolumn{7}{|l|}{ Significance } \\
\hline Application (A) & $* * *$ & $* * *$ & $* * *$ & $* * *$ & n.s. & $* *$ \\
\hline Storage (B) & $* * *$ & $* * *$ & $* * *$ & $* * *$ & $* * *$ & $* * *$ \\
\hline $\mathrm{A} \times \mathrm{B}$ & n.s. & n.s. & $* * *$ & * & n.s. & $* * *$ \\
\hline
\end{tabular}


Table 5. Influence of way of compost extract application (C: control, CENS: compost extract in the nutrient solution, CEMP: compost extract delivered by microsprinkler) and storage ( 0 and 7 days) at $5{ }^{\circ} \mathrm{C}$ on the quality (nitrate, total phenolics, total flavonoids and antioxidant capacity) and microbial load (mesophilic and psychrophilic microorganisms) of baby leaf red lettuce cultivated in autumn cycle in a floating system.

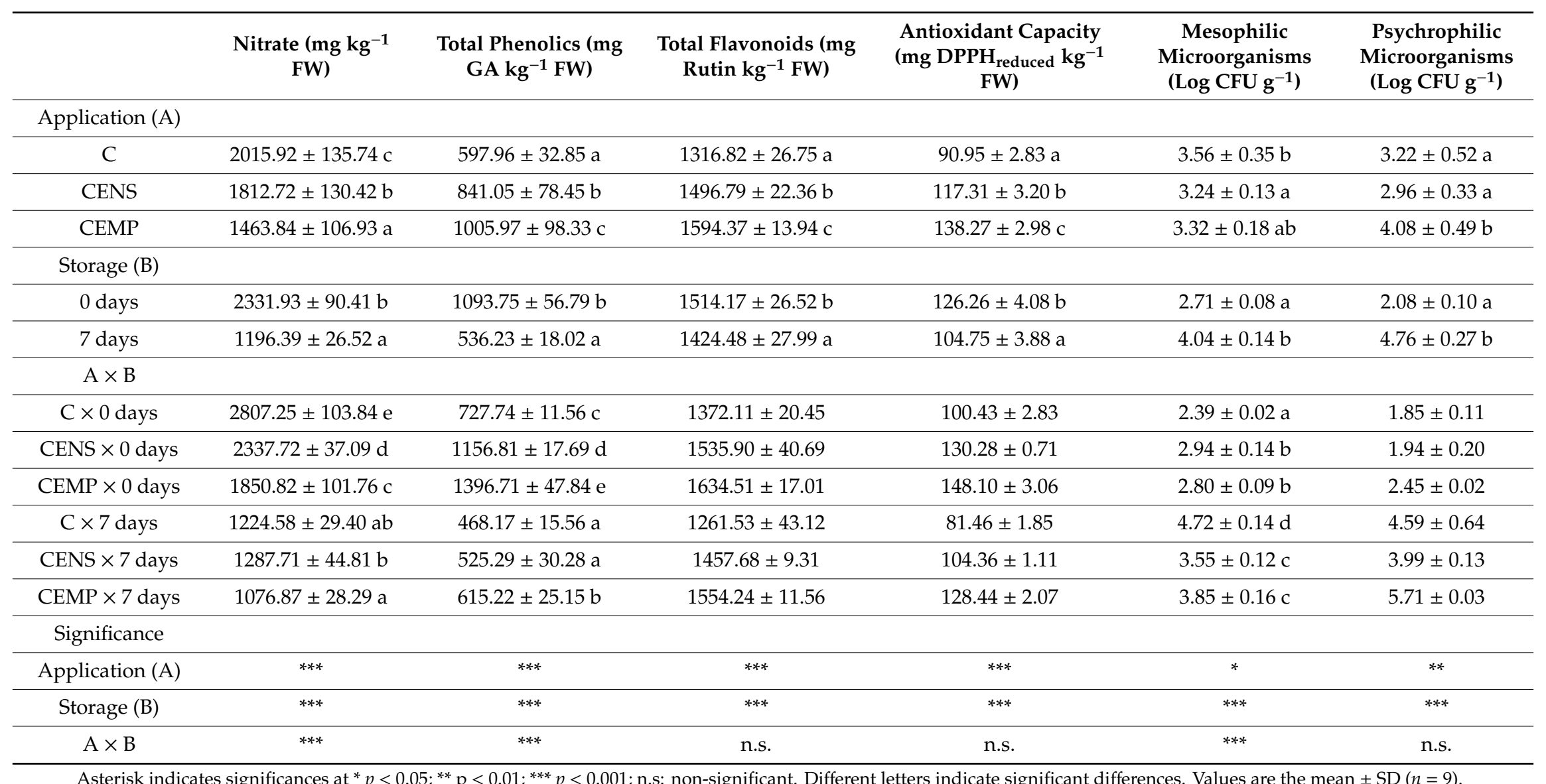


The total phenolics content was affected by the way of CE application and storage in the winter-spring cycle (Table 4). The leaves of plants grown with CEMP had the highest content. In the autumn cycle, there was a significant interaction between both factors, the highest value is reached with the CEMP application at harvesting (Table 5). Storage decreased the phenolics content in every CE treatment in both cycles.

There was a significant interaction between both factors for the total flavonoids content and antioxidant capacity in the winter-spring cycle, the highest values for total flavonoids obtained with CEMP and CENS and the highest antioxidant capacity with CEMP. Total flavonoids had decreased in all the CE treatments (50\%, 21\% and 22\% for control, CENS and CEMP, respectively) after 7 days of storage. The antioxidant capacity also decreased for each treatment after 7 days of storage, but with only slight differences between them. In the autumn cycle, the total flavonoids content and antioxidant capacity were affected by both factors. Both values were higher when $C E$ was applied, particularly with the CEMP application. Storage decreased both parameters in both cycles.

The microbial load for mesophilic microorganisms was only affected by storage in the winter-spring cycle, whereas there was an interaction between both factors in the autumn cycle, the highest value being found at day 7 in the leaves from the control plants. There was a significant interaction between both factors for psychrophilic microorganisms in the winter-spring cycle, in this case, the highest value is found at day 7 in the leaves from plants grown in CENS. However, the microbial load for psychrophilic microorganisms was affected by both factors in the autumn cycle, the highest load is found in the leaves of plants grown with CEMP application.

\section{Discussion}

The effect of CE on growth differed depending on the way it was applied. CENS application provided the highest yield (Tables 1 and 2). The nitrate concentration of the irrigation water, which increased weekly due to its gradual release from CE in the CENS application (data not shown), may have influenced the increase in lettuce yield. The use of $\mathrm{CE}$ in the nutrient solution could provide benefits both as fertilizer and biostimulant [30]. The application of CENS also reduced the incidence of the pathogen added to the water (Figure 1), due to the suppressive effect of the compost, again increasing the crop yield. Giménez et al. 2019 [13] demonstrated that the same compost lowered the incidence of $P$. irregulare, producing higher yields in lettuce when the substrate was infected by the pathogen. Conversely, the CEMP application did not increase yield in spite of the additional $13.4 \mathrm{mg} / \mathrm{L}$ of nitrate, on average, in each microsprinkler irrigation event (Table 1). In addition, the $\mathrm{Na}^{+}$ and $\mathrm{Cl}^{-}$concentration could have had a higher negative influence in the growth when $\mathrm{CE}$ was applied by microsprinkler than directly to the nutrient solution, although the plants did not show symptoms of phytotoxicity. However, this way of CE application also reduced the concentration of P. irregulare in the water (Figure 1). A decrease in SLA is related to an increase in leaf thickness; in our experiment, CE application decreased SLA in inoculation conditions, particularly in the autumn cycle. Panova et al. 2011 [38] found a decrease in SLA values in cucumber plants inoculated with a moderate concentration of Pythium aphanidermatum, although SLA increased with a high concentration of the pathogen. The treatments with CE could have induced a greater resistance to the fungus, as manifested by the greater thickness of the leaves. In addition, the total root length and fine roots were significantly higher in CENS, confirming the importance of a healthy root system for the plants to use the water and nutrients in the most efficient way, and thus provide high yields. This beneficial effect of CE, whose application was more efficient when directly applied to the nutrient solution (CENS), on yield and/or root length could be due to the production of auxin or auxin-like components from humic substances [39], which would promote radicular growth. Inoculation with $P$. irregulare reduced root length and increased the root diameter in every treatment (Tables 1 and 2). Our results agree with those of Schwarz and Grosch 2003 [40], who found that after the inoculation of tomato with P. aphanidermatum the number and length of roots were significantly reduced, the strongest effect being on young and fine roots, while an increase in root diameter was also detected. In general, Pythium spp. causes a reduction 
in root length [41], while root diameter is generally the most responsive plant trait associated with inoculation by root rot pathogens [42].

The reduction of $P$. irregulare in the water to CE had been applied (Figure 1) could be attributed to antibiotic-like compounds or microorganisms [2,7] from the original compost [12]. This demonstrates that the suppressiveness observed in compost is probably transferred and maintained in its water extract, reducing pathogen incidence as a direct effect [30,43]. Indirectly, the presence of compounds or microorganisms capable of triggering plant resistance would provoke an over-reduction of the pathogen in the water solution by excreting antimicrobial compounds through the root system [43-45].

The nitrate content is an important quality characteristic of vegetables [46], and the EU encourages good agricultural practices to reduce the presence of nitrates in lettuce by imposing a limit for its sale [47]. Our data suggest that the use of compost extract, both as CENS and CEMP, reduced the amount of nitrate compared with the control, increasing the quality of the baby leaf red lettuce. This might be the result of the biostimulant effect of the compost, inducing changes in the expression of nitrate transporter genes, as well as in several metabolic pathways involved in $\mathrm{N}$ metabolism (nitrate and nitrite reductase, glutamate synthase and glutamine synthetase activities), leading to a more efficient assimilation of nitrates into amino acids [48,49]. Of note was the capacity of the compost to reduce this content when plants were grown with the CEMP application. Possibly, the above-mentioned increase on the nitrate concentration of the nutrient solution due to its gradual release from the CENS application would be responsible for the nitrate level in leaves being slightly higher in CENS than in the CEMP. The nitrate concentrations were higher in the autumn cycle, as was expected since DLI was lower in the autumn than in the winter-spring cycle. This is because light conditions influence nitrate reductase activity and decrease the conversion rate of nitrate to amino acids, leading to a higher concentration of nitrates [50,51]. Moreover, nitrate concentrations did not exceed the maximum level allowed by the EU for this type of lettuce and way of cultivation. After 7 days of storage at $5{ }^{\circ} \mathrm{C}$, the nitrate concentration in leaves had been reduced. Our findings agree with the results of Gomez et al. 2003 [52] in celery and Miceli et al. 2019 [53] in rocket leaves, where a general decrease in the nitrate content of leaves was observed after storage at $4{ }^{\circ} \mathrm{C}$. By contrast, Konstantopoulo et al. 2010 [54] and Miceli et al. 2019 [53] showed that the nitrate content remained constant in different types of green lettuce during storage at 5 and $10{ }^{\circ} \mathrm{C}$ and at $4{ }^{\circ} \mathrm{C}$, respectively. As the nitrate content of leaves and changes in the same during cold storage are species-dependent, red lettuce might have a different nitrate accumulation pattern from green lettuce [55,56], its content during cold storage falling as a consequence.

The postharvest quality of fresh vegetables is generally influenced by several preharvest factors and environmental conditions [57]. Hence, the CE application used could have resulted in the induction and activation of the plant secondary metabolism, increasing the content of total phenolics and flavonoids and the antioxidant capacity compared with the control plants at harvest (Tables 3 and 4). As regards phenolic compounds, these results agree with those of Kołton and Baran, 2008 [58], who found that compost application significantly increased the phenol content in corn salad compared with mineral fertilization. Also, the fruit of pepper plants grown with carrot compost had a high phenol content [59]. Nevertheless, in pak choi total phenolics were lower in vermicompost tea-treated plants than in plants treated with only mineral nutrient solution and those from the water-only control [60]. Regarding total flavonoids at harvest, our results agree with those of Khalid et al. 2006 [45] and Ezz El-Din et al. [43], who showed that the concentration of flavonoids increased significantly following compost tea treatments. Likewise, higher flavonoid contents were observed in Moringa oleifera plants treated with NPK + compost [61]. Similarly, the antioxidant capacity at harvest was higher in CE treated plants, (Tables 2 and 3) as reported in other studies where compost was applied to lettuce, spinach $[62,63]$ and pak choi [60]. Lettuce leaves accumulated significantly more phenolic compounds and flavonoids in the autumn than in the winter-spring cycle at harvest probably due to the difference in temperature and light between cycles, as suggested by Marin et al. 2015 [64] in red oak lettuce, who found a positive correlation between the content of phenolic acids and flavonoids and 
cold temperatures. Among environmental factors, light/radiation and temperature are the two most influential climatic variables for the biosynthesis of phenolics in red lettuce [65]. Furthermore, other authors have suggested that there is competition between the flavonoid and phenolic acids pathways, the flavonoids route being favored in conditions of high light intensity [66], since they can act as photoprotectors as occurred in the winter-spring cycle of our experiment (Table 4), which had a higher DLI than the autumn cycle. In the winter-spring cycle, too, there was a positive correlation between phenolic compounds and antioxidant capacity $(\mathrm{r}=0.891, p \leq 0.01 ; \mathrm{r}=0.942, p \leq 0.01$ and $\mathrm{r}=0.846$, $p \leq 0.01$ for control, CENS and CEMP treatment, respectively) and also between flavonoids and the antioxidant capacity $(\mathrm{r}=0.941, p \leq 0.01, \mathrm{r}=0.917, p \leq 0.01, \mathrm{r}=0.463, p \geq 0.5$ for control, CENS and CEMP treatment, respectively). However, in the autumn cycle this positive relation was only evident between total phenolics and the antioxidant capacity $(\mathrm{r}=0.817 p \leq 0.01, \mathrm{r}=0.966, p \leq 0.01, \mathrm{r}=0.770$, $p \leq 0.01$, for control, CENS and CEMP, respectively) and there was no correlation with flavonoids. These data indicate that flavonoids could have an important role in radical-scavenging [67], as was seen in the winter-spring cycle when the amount of them was higher.

After 7 days of storage, the total phenolics and flavonoids and the antioxidant capacity were significantly lower than at harvest time, as was observed by Kalt et al. 1999 [68], Serafini et al. 2002 [69] and Ninfali and Bacchiocca 2005 [70]. The decrease in total phenolics that occurs during storage may be due to increased antioxidant enzymatic activities [71]. However, other authors found that total flavonoids remained quite constant in spinach [72] and the phenolic contents increased in lettuce [73]. DuPont et al. 2000 [74] reported the loss of flavonol glycosides in lettuce stored at $1{ }^{\circ} \mathrm{C}$ for $7 \mathrm{~d}$, confirming that significant changes in the relative concentration of individual phenolics that may occur during storage are sometimes cultivar-dependent.

Since lettuce is consumed raw, information on possible microbial contamination is of great importance. As expected, mesophilic and psychrophilic populations increased significantly during the storage period, but were below $6 \log$ units at the end of product shelf-life (Tables 3 and 4). These values were lower than those reported in previous studies in red lettuce [75]. Our results demonstrated that microbial quality was maintained during storage and that $C E$ treatment had no negative effect on the microbial load of the product, with values typical for fresh-cut lettuce ready for marketing.

\section{Conclusions}

Directly brewed compost extract added to the nutrient solution improves baby leaf lettuce growth and quality (reducing the nitrate content and enhancing the content of potentially health-promoting compounds such as total phenolics and flavonoids as well as the antioxidant capacity). The application of compost extract by microsprinkler slightly reduces plant growth, but notably increases the quality of the product. The microbial quality is maintained during shelf-life and compost extract has no negative effect on the microbial load of the final product. In addition, both ways of compost extract application decrease the population of Pythium irregulare in the water. However, further studies are needed on the application of compost extract in order to develop sustainable agricultural production based on the reduced use of fertilizers.

Author Contributions: J.A.F., J.A.P. and C.E.-G. conceived and designed the experiments. A.G. conducted the experiments, performed the analyses, collected the data and made the statistical evaluations. J.A.F. and C.E.-G. wrote the manuscript. J.A.P. and M.R. revised the manuscript critically for important intellectual content. All authors have read and agreed to the published version of the manuscript.

Funding: This research was funded by Ministerio de Economía y Competitividad of Spain, projects AGL2017-84085-C3-3-R and AGL-2014-52732-C2-2-R.

Acknowledgments: This work was supported by projects AGL2017-84085-C3-3-R and AGL2017-84085-C3-1-R from the Ministerio de Economía y Competitividad of Spain.

Conflicts of Interest: The authors declare no competing financial interests. 


\section{References}

1. Razza, F.; D'Avino, L.; L'Abate, G.; Lazzeri, L. The role of compost in bio-waste management and circular economy. In Designing Sustainable Technologies, Products and Policies; Benetto, E., Gericke, K., Guiton, M., Eds.; Springer Nature: Cham, Switzerland, 2018; pp. 133-143.

2. Bernal-Vicente, A.; Ros, M.; Tittarelli, F.; Intrigliolo, F.; Pascual, J.A. Citrus compost and its water extract for cultivation of melon plants in greenhouse nurseries. Evaluation of nutriactive and biocontrol effects. Bioresour. Technol. 2008, 99, 8722-8728. [CrossRef] [PubMed]

3. Blaya, J.; Lloret, E.; Ros, M.; Pascual, J.A. Identification of predictor parameters to determine agro-industrial compost suppressiveness against Fusarium oxysporum and Phytophthora capsici diseases in muskmelon and pepper seedlings. J. Sci. Food Agric. 2015, 95, 1482-1490. [CrossRef] [PubMed]

4. Ronga, D.; Villecco, D.; Zaccardelli, M. Effects of compost and defatted oilseed meals as sustainable organic fertilisers on cardoon (Cynara cardunculus L.) production in the Mediterranean basin. J. Hortic. Sci. Biotechnol. 2019, 94, 664-675. [CrossRef]

5. Moretti, S.M.L.; Bertoncini, I.B.; Abreu-Junior, C.H. Composting sewage sludge with green waste from tree pruning. Sci. Agric. 2015, 72, 432-439. [CrossRef]

6. Ros, M.; Hernández, M.T.; García, C.; Bernal, A.; Pascual, J.A. Biopesticide effect on Green compost against fusarium wilt on melon plants. J. Appl. Microbiol. 2015, 98, 845-854. [CrossRef]

7. Pascual, J.A.; Garcia, C.; Hernandez, T.; Lerma, S.; Lynch, J.M. Effectiveness of municipal waste compost and its humic fraction in suppressing Pythium ultimum. Microb. Ecol. 2002, 44, 59-68. [CrossRef]

8. Hoitink, H.A.J.; Fahy, P.C. Basis for the control of soilborne plant pathogens with composts. Annu. Rev. Phytopathol. 1986, 24, 93-114. [CrossRef]

9. Noble, R.; Coventry, E. Suppression of soil-borne plant diseases with composts: A review. Biocontrol Sci. Technol. 2005, 15, 3-20. [CrossRef]

10. Hoitink, H.A.J.; Grebus, M.E. Composts and the control of plant disease. In Humic Substances in Soil, Peats and Waters: Health and Enviromental Aspects; Hayes, M.H.B., Wilson, W.S., Eds.; Royal Society of Chemistry: Cambrige, UK, 1997; pp. 359-366.

11. Ronga, D.; Pane, C.; Zaccardelli, M.; Pecchioni, N. Use of spent coffee ground compost in peat-based growing media for the production of basil and tomato potting plants. Commun. Soil Sci. Plant Anal. 2016, 47, 356-368. [CrossRef]

12. Giménez, A.; Fernández, J.A.; Pascual, J.A.; Ros, M.; López-Serrano, M.; Egea-Gilabert, C. An agroindustrial compost as alternative to peat for production of baby leaf red lettuce in a floating system. Sci. Hortic. 2019, 246, 907-915. [CrossRef]

13. Giménez, A.; Fernández, J.A.; Egea-Gilabert, C.; Santísima-Trinidad, A.B.; Ros, M.; Pascual, J.A. Agro-industry composts as growing medium for growing baby-leaf lettuces in a floating system-Added-value to suppress Pythium irregulare. Acta Hortic. 2019, 1242, 791-798. [CrossRef]

14. Zhang, W.; Han, D.Y.; Dick, W.A.; Davis, K.R.; Hoitink, H.A.J. Compost and compost water extract-induced systemic acquired resistance in cucumber and Arabidopsis. Phytopathology 1998, 88, 450-455. [CrossRef] [PubMed]

15. Litterick, A.M.; Harrier, L.; Wallace, P.; Watson, C.A.; Wood, M. The role of uncomposted materials, composts, manures, and compost extracts in reducing pest and disease incidence and severity in sustainable temperate agricultural and horticultural crop production-A review. Crit. Rev. Plant Sci. 2004, 23, 453-479. [CrossRef]

16. Dafermos, N.G.; Kasselaki, A.M.; Goumas, D.E.; Eyre, M.D.; Spandidakis, K.; Leifert, C. Integration of elicitors and less susceptible hybrids for the control of powdery mildew in organic tomato crops. Plant Dis. 2012, 96, 1506-1512. [CrossRef] [PubMed]

17. Giotis, C.; Theodoropoulou, A.; Cooper, J.; Hodgson, R.; Shotton, P.; Shiel, R.; Eyre, M.; Wilcockson, S.; Markellou, E.; Liopa-Tsakalidis, A.; et al. Effect of variety choice, resistant rootstocks and chitin soil amendments on soil-borne diseases in soil-based, protected tomato production systems. Eur. J. Plant Pathol. 2012, 134, 605-617. [CrossRef]

18. Diver, S.; Greer, L. Sustainable Small-Scale Nursery Production. Horticulturae System Guide. ATTRA. 2001. Available online: http://www.attra.org/attra-pub/PDF/nursery.pdf (accessed on 20 November 2018).

19. Eyheraguibel, S.J.; Morard, P. Effects of humic substances derived from organic waste enhancement on the growth and mineral nutrition of maize. Bioresour. Technol. 2008, 99, 4206-4212. [CrossRef] 
20. Arancon, N.Q.; Pant, A.; Radovich, T.; Nguyen, V.H.; Potter, J.; Converse, C. Seed germination and seedling growth of lettuce and tomato as affected by vermicompost water extracts (teas). HortScience 2012, 47, 1722-1728. [CrossRef]

21. Khaled, H.; Fawy, H.A. Effect of different levels of humic acids on the nutrient content, plant growth, nd soil properties under conditions of salinity. Soil Water Res. 2011, 6, 21-29. [CrossRef]

22. Morard, P.; Eyheraguibel, B.; Morard, M.; Silvestre, J. Direct effects of humic-like substance on growth, water, and mineral nutrition of various species. J. Plant Nutr. 2011, 34, 46-59. [CrossRef]

23. Nardi, S.; Pizzeghello, D.; Muscolo, A.; Vianello, A. Physiological effects of humic substances on higher plants. Soil Biol. Biochem. 2002, 34, 1527-1536. [CrossRef]

24. St. Martin, C.C.G.; Brathwaite, R.A.I. Compost and compost tea: Principles and prospects as substrates and soil-borne disease management strategies in soil-less vegetable production. Biol. Agric. Hortic. 2012, 28, 1-33. [CrossRef]

25. Al-Dahmani, J.H.; Abbasi, P.A.; Miller, S.A.; Hoitink, H.A.J. Suppression of bacterial spot of tomato with foliar sprays of compost extracts under greenhouse and field conditions. Plant Dis. 2003, 87, 913-919. [CrossRef] [PubMed]

26. Welke, S.E. The effect of compost extract on the yield of strawberries and the severity of Botrytis cinerea. J. Sustain. Agric. 2005, 25, 57-68. [CrossRef]

27. Koné, S.B.; Dionne, A.; Tweddell, R.J.; Antoun, H.; Avis, T.J. Suppressive effect of non-aerated compost teas on foliar fungal pathogens of tomato. Biol. Control 2010, 52, 167-173. [CrossRef]

28. Arancon, N.Q. Suppression of arthropod pests and diseases using vermicompost teas. In Tea Time in the Tropics: A Handbook of Compost Tea Production and Use; Radovich, T., Arancon, N.Q., Eds.; College of Tropical Agriculture and Human Resources, University of Hawaii: Honolulu, HI, USA, 2011; pp. 41-58.

29. Kim, M.J.; Shim, C.K.; Kim, Y.K.; Hong, S.J.; Park, J.H.; Han, E.J.; Kim, J.H.; Kim, S.C. Effect of aerated compost tea on the growth promotion of lettuce, soybean, and sweet corn in organic cultivation. Plant Pathol. J. 2015, 31, 259-268. [CrossRef] [PubMed]

30. Zaccardelli, M.; Pane, C.; Villecco, D.; Palese, A.M.; Celano, G. Compost tea spraying increases yield performance of pepper (Capsicum annuum L.) grown in greenhouse under organic farming system. Ital. J. Agron. 2018, 13, 229-234. [CrossRef]

31. Radovich, T.; Arancon, N.Q. Tea Time in the Tropics: A Handbook of Compost Tea Production and Use; College of Tropical Agriculture and Human Resources, University of Hawaii: Manoa, HI, USA, 2011.

32. Egea-Gilabert, C.; Fernández, J.A.; Migliaro, D.; Martínez-Sánchez, J.J.; Vicente, M.J. Genetic variability in wild vs. cultivated Eruca vesicaria populations as assessed by morphological, agronomical and molecular analyses. Sci. Hortic. 2009, 121, 260-266. [CrossRef]

33. Lara, L.J.; Egea-Gilabert, C.; Niñirola, D.; Conesa, E.; Fernández, J.A. Effect of aeration of the nutrient solution on the growth and quality of purslane (Portulaca oleracea). J. Hortic. Sci. Biotechnol. 2011, 86, 603-610. [CrossRef]

34. Everette, J.D.; Bryant, Q.M.; Green, A.M.; Abbey, Y.A.; Wangila, G.M.; Walker, R.B. Through study of reactivity of various compound classes toward the Folin-Ciocalteu reagent. J. Agric. Food Chem. 2010, 58, 8139-8144. [CrossRef]

35. Brand-Williams, W.; Cuvelier, M.E.; Berset, C. Use of free radical method to evaluate antioxidant activity. Lebensm. Wiss. Technol. 1995, 28, 25-30. [CrossRef]

36. Meda, A.; Lamien, C.E.; Romito, M.; Millogo, J.; Nacoulma, O.G. Determination of the total phenolic, flavonoid and proline contents in Burkina Fasan honey, as well as their radical scavenging activity. Food Chem. 2005, 91, 571-577. [CrossRef]

37. Niñirola, D.; Fernández, J.A.; Conesa, E.; Martínez, J.A.; Egea-Gilabert, C. Combined effects of growth cycle and different levels of aeration in nutrient solution on productivity, quality and shelf-life of watercress (Nasturtium officinale R. Br.) plants. HortScience 2014, 49, 567-573. [CrossRef]

38. Panova, G.G.; Heibner, A.; Grosch, R.; Kläring, H.P. Pythium aphanidermatum may reduce cucumber growth without affecting leaf photosynthesis. J. Phytopathol. 2012, 160, 37-40. [CrossRef]

39. Trevisan, S.; Francioso, O.; QuaggiottI, S.; Nardi, S. Humic substances biological activity at the plant-soil interface: From environmental aspects to molecular factors. Plant Signal. Behav. 2010, 5, 635-643. [CrossRef] [PubMed] 
40. Schwarz, D.; Grosch, R. Influence of nutrient solution concentration and a root pathogen (Pythium aphanidermatum) on tomato root growth and morphology. Sci. Hortic. 2003, 97, 109-120. [CrossRef]

41. Wulff, E.G.; Pham, A.T.H.; Ch'erif, M.; Rey, P.; Tirilly, Y.; Hockenhull, J. Inoculation of cucumber roots with zoospores of mycoparasitic and plant pathogenic Pythium species: Differential zoospore accumulation, colonization ability and plant growth response. Eur. J. Plant Pathol. 1998, 104, 69-76. [CrossRef]

42. Biernacki, M.; Bruton, B.D. Comparison of leaf-area index with root weight for assessing plant damage by soil-borne pathogens. Acta Hortic. 2000, 510, 163-170. [CrossRef]

43. Ezz El-Din, A.A.; Hendawy, S.F. Effect of dry yeast and compost tea on growth and oil content of borago officinalis plant. Res. J. Agric. Biol. Sci. 2010, 6, 424-430.

44. Keeling, A.A.; McCallum, K.R.; Beckwith, C.P. Mature green waste compost enhances growth and nitrogen uptake in wheat (Triticum aestivum L.) and oilseed rape (Brassica napus L.) through the action of water-extractable factors. Bioresour. Technol. 2003, 90, 127-132. [CrossRef]

45. Khalid, K.A.; Hendawy, S.F.; El-Gezawy, E. Ocimum basilicum L. production under organic farming. Res. J. Agric. Biol. Sci. 2006, 2, 25-32.

46. Santamaria, P. Nitrate in vegetables: Toxicity, content, intake and EC regulation. J. Sci. Food Agric. 2006, 86, 10-17. [CrossRef]

47. European Union. Commission Regulation (EU) n 1258/2011 of 2 December 2011 Amending Regulation (EC) $\mathrm{n}^{\circ}$ 1881/2006 As Regards Maximum Level for Nitrates in Foodstuffs. Off. J. Eur. Union L 2011, 320, $15-17$.

48. Tsouvaltzis, P.; Koukounaras, A.; Siomos, S.A. Application of amino acids improves lettuce crop uniformity and inhibits nitrate accumulation induced by the supplemental inorganic nitrogen fertilization. Int. J. Agric. Biol. 2014, 16, 951-955.

49. Colla, G.; Kim, H.J.; Kyriacou, M.C.; Rouphael, Y. Nitrate in fruits and vegetables. Sci. Hortic. 2018, 237, 221-238. [CrossRef]

50. Tamme, T.; Reinik, M.; Roasto, M. Nitrates and nitrites in vegetables: Occurrence and health risks. In Bioactive Foods Promoting Health: Fruits and Vegetables; Watson, R.R., Preedy, V.R., Eds.; Academic Press: Salt Lake City, UT, USA, 2009; pp. 307-321.

51. Burns, I.G.; Zhang, K.; Turner, M.K.; Edmondson, R. Iso-osmotic regulation of nitrate accumulation in lettuce. J. Plant Nutr. 2010, 34, 283-313. [CrossRef]

52. Gómez, P.; Artés, F.; Madrid, R. Nitrogen fertiliser rate and controlled atmospheres effects on the nitrates levels and quality of fresh processed celery sticks. Acta Hortic. 2003, 604, 493-498. [CrossRef]

53. Miceli, A.; Vetrano, F.; Sabatino, L.; D’Anna, F.; Moncada, A. Influence of preharvest gibberellic acid treatments on postharvest quality of minimally processed leaf lettuce and rocket. Horticulturae 2019, 5, 63. [CrossRef]

54. Konstantopoulo, E.; Kapotis, E.; Salachas, G.; Petropoulos, S.A.; Karapanos, I.C.; Passam, H.C. Nutritional quality of greenhouse lettuce at harvest and after storage in relation to $\mathrm{N}$ application and cultivation season. Sci. Hort. 2010, 125, 93-94. [CrossRef]

55. Becker, C.; Urlić, B.; Jukić Špika, M.; Kläring, H.P.; Krumbein, A.; Baldermann, S.; Goreta Ban, S.; Perica, S.; Schwarz, D. Nitrogen limited red and green leaf lettuce accumulate flavonoid glycosides, caffeic acid derivatives, and sucrose while losing chlorophylls, $\beta$-carotene and xanthophylls. PLoS ONE 2015, 10, e0142867. [CrossRef]

56. Viršilè, A.; Brazaitytè, A.; Vaštakaitė-Kairienè, V.; Miliauskienė, J.; Jankauskienè, J.; Novičkovas, A.; Samuolienè, G. Lighting intensity and photoperiod serves tailoring nitrate assimilation indices in red and green baby leaf lettuce. J. Sci. Food Agric. 2019, 99, 6608-6619. [CrossRef]

57. Yahia, E.M.; Gardea-Béjar, A.; Ornelas-Paz, J.J.; Maya-Meraz, O.; Rodríguez-Roque, M.J.; Rios-Velasco, C.; Ornelas-Paz, J.; Salas-Marina, M.A. Preharvest factors affecting postharvest quality. In Postharvest Technology of Perishable Horticultural Commodities; Yahia, E.M., Ed.; Elsevier: Cambridge, UK, 2019; pp. 99-128.

58. Kołton, A.; Baran, A. Effect of Different Mineral Nitrogen and Compost Nutrition on Some Compounds of Corn Salad (Valerianella Locusta (L.) Latter; Lithuanian Institute of Horticulture; Lithuanian University of Agriculture: Babtai, Kaunas District, Lithuania, 2008; Volume 27, pp. 379-387.

59. Fiasconaro, M.L.; Lovato, M.E.; Antolín, M.C.; Clementi, L.A.; Torres, N.; Gervasio, S. Role of proline accumulation on fruit quality of pepper (Capsicum annuum L.) grown with a K-rich compost under drought conditions. Sci. Hortic. 2019, 249, 280-288. [CrossRef] 
60. Pant, A.; Radovich, T.J.K.; Hue, N.V.; Arancon, N.Q. Effects of vermicompost tea (aqueous extract) on pak choi yield, quality, and on soil biological properties. Compost Sci. Util. 2011, 19, 279-292. [CrossRef]

61. Sarwar, M.; Patra, J.K.; Ali, A.; Maqbool, M.; Arshad, M.I. Effect of compost and NPK fertilizer on improving biochemical and antioxidant properties of Moringa oleifera. S. Afr. J. Bot. 2019. [CrossRef]

62. Haghighi, M. Sewage sludge application in soil improved leafy vegetable growth. J. Biol. Environ. Sci. 2011, 5, 165-167.

63. Tavarinia, S.; Cardellia, R.; Saviozzia, A.; Degl'Innocentia, E.; Guidia, L. Effects of green compost on soil biochemical characteristics and nutritive quality of leafy vegetables. Compost Sci. Util. 2011, 19, 114-122. [CrossRef]

64. Marin, A.; Ferreres, F.; Barberá, G.G.; Gil, M.I. Weather variability influences color and phenolic content of pigmented baby leaf lettuces throughout the season. J. Agric. Food Chem. 2015, 63, 1673-1681. [CrossRef]

65. Oh, M.M.; Carey, E.E.; Rajashekar, C.B. Environmental stresses induce health-promoting phytochemicals in lettuce. Plant Physiol. Biochem. 2009, 47, 578-583. [CrossRef]

66. Pérez-López, U.; Sgherrib, C.; Miranda-Apodacaa, J.; Micaellib, F.; Lacuestac, M.; Mena-Petitea, A.; Quartaccib, M.F.; Muñoz-Rueda, A. Concentration of phenolic compounds is increased in lettuce grown under high light intensity and elevated $\mathrm{CO}_{2}$. Plant Physiol. Biochem. 2018, 123, 233-241. [CrossRef]

67. Ouzounis, T.; Parjikolaei, B.R.; Fretté, X.; Rosenqvist, E.; Ottosen, C.O. Predawn and high intensity application of supplemental blue light decreases the quantum yield of PSII and enhances the amount of phenolic acids, flavonoids, and pigments in Lactuca sativa. Front. Plant Sci. 2015, 6, 1-14. [CrossRef]

68. Kalt, W.; Forney, C.F.; Martin, A.; Prior, R.L. Antioxidant capacity, vitamin C, phenolics, and anthocyanins after fresh storage of small fruits. J. Agric. Food Chem. 1999, 47, 4638-4644. [CrossRef]

69. Serafini, S.; Bugianesi, R.; Salucci, M.; Azzini, E.; Raguzzini, A.; Maiani, G. Effect of acute ingestion of fresh and stored lettuce (Lactuca sativa) on plasma total antioxidant capacity and antioxidant levels in human subjects. Br. J. Nutr. 2002, 88, 615-623. [CrossRef] [PubMed]

70. Ninfali, P.; Mea, G.; Giorgini, S.; Rocchi, M.; Bacchiocca, M. Antioxidant capacity of vegetables, spices and dressings relevant to nutrition. Br. J. Nutr. 2005, 93, 257-266. [CrossRef] [PubMed]

71. Islam, R.; Sultana, S.; Rejaul Islam, M.D.; Monda, C. Effect of aerated and non-aerated compost tea against some fungal phytopathogens. J. Bangladesh Agric. Univ. 2019, 17, 142-147. [CrossRef]

72. Gil, M.I.; Ferreres, F.; Tomás-Barberá, F.T. Effect of postharvest storage and processing on the antioxidant constituents (flavonoids and vitamin C) of fresh-cut spinach. J. Agric. Food Chem. 1999, 47, 2213-2217. [CrossRef] [PubMed]

73. Zhao, X.; Iwamoto, T.; Carey, E.E. Antioxidant capacity of leafy vegetables as affected by high tunnel environment, fertilisation and growth stage. J. Sci. Food Agric. 2007, 87, 2692-2699. [CrossRef]

74. DuPont, M.S.; Mondin, Z.; Williamson, G.; Price, K.R. Effect of variety, processing, and storage on the flavonoid glycoside content and composition of lettuce and endive. J. Agric. Food Chem. 2000, 48, 3957-3964. [CrossRef]

75. Selma, M.V.; Luna, M.C.; Martínez-Sánchez, A.; Tudela, J.A.; Beltrán, D.; Baixauli, C.; Gil, M.I. Sensory quality, bioactive constituents and microbiological quality of green and red fresh-cut lettuces (Lactuca sativa L.) are influenced by soil and soilless agricultural production systems. Postharvest Biol. Technol. 2012, 63, 16-24. [CrossRef]

(C) 2020 by the authors. Licensee MDPI, Basel, Switzerland. This article is an open access article distributed under the terms and conditions of the Creative Commons Attribution (CC BY) license (http://creativecommons.org/licenses/by/4.0/). 